لذلك فان الجانب الأساسي في هذا البحث هو التميز والتثريق

بين كلا من: (1) البيئة الداخلية، (Y) البيئة الخارجية، (r)

عملية صنع القزار في السياسه الخارجيه. 
Zinnes, Dina. "Some Evidence Relevant to the Man-Milieu Hypothesis", in James Rosenau (ed.). The Analysis of International Politics. N.Y.: The Free Press, 1982.

\section{The Determinants of Foreign Policy}

Abstract: This paper will discuss the different ways in which theorists have classified the determinants of foreign policy. All theories of foreign policy divide the factors influencing policy into domestic and external factors.

The most fundamental aspect of such a framework must be the distinction between the external environment, the domestic environment and the decision-making process.

\section{محددات السياسه الخارجيه}

$$
\begin{aligned}
& \text { ملخص البحث: يناتش البحث عده طرق واتجاهات مختلة استخمها منظري } \\
& \text { السياسه الخارجيه في تصنيف محدات السياسه الخارجيه. } \\
& \text { ومعظم نظريات السياسه الخارجيه تقسم العوامل المؤثرة في } \\
& \text { السياسه الخارجيه إلى عوامل داخلية وعوامل خارجية. }
\end{aligned}
$$


Padelford, Norman and George Lincoln. The Dynamics of International Politics. London: MacMillan Press, 1972.

Ramazani, Rouhollah. The Foreign Policy of Iran 1500-1941.

Virginia: University of Virginia Press, 1966.

Robinson, James and Richard Snyder. "Decision-Making in International Politics", in Herbert Kelman (ed.). International Behavior: A Social-Psychological Analysis. N.Y.: Holt, Rinehart and Winston, 1985.

Rosecrance, Richard. International Relations: Peace or War. N.Y.: McGraw Hill Book, 1983.

Rosenau, James. The Scientific Study of Foreign Policy. N.Y.: Nicholas Publishing Co., 1980.

Sondermann, Fred, William Olson and David McLellan. The Theory and Practice of International Relations. Englewood Cliffs: Prentice-Hall, 1983.

Sprout, Harold and Margaret. "Environment Factors in the Study of International Politics", in James Rosenau (ed.). International Politics and Foreign Policy: A Reader in Research and Theory. N.Y.: The Free Press, 1969.

Sprout, Harold and Margaret. Foundations of International Politics. N.J.: D. Van Nostrand Co., 1972.

Sprout, Harold and Margaret. The Ecological Perspective on Human Affairs with Special Reference to International Politics. Princeton: Princeton University Press, 1975.

Wright, Quincy. A Study of War. Chicago: University of Chicago Press, 1965. 
Glassman, Jon. "Soviet Foreign Policy Decision-Making", in Andrew Cordier (ed.). Columbia Essays in International Affairs, Vol. 3. N.Y.: Columbia University Press, 1978.

Holsti, K.J. "Domestic Factors and Foreign Policy Outputs", in Janies Barber and Michael Smith (eds.). The Nature of Foreign Policy: A Reader. Edinburgh: Holmes McDougall, 1984.

Jervis, Robert. Perception and Misperception in International Politics.

Princeton: Princeton University Press, 1976.

Jones, Roy. Principles of Foreign Policy. Oxford: Martin Robertson Co., 1979.

Kissinger, Henry. "Domestic Structure and Foreign Policy", in James Rosenau (ed.). International Politics and Foreign Policy: A Readier in Research and Theory. N.Y.: The Free Press, 1969. Macridis, Roy. Foreign Policy in World Politics. Englewood Cliffs: Printice-Hall, 1977.

McGowan, Patrick and Howard Shapiro. The Comparative Study of Foreign Policy. London: Sage Publications, 1983.

Miller, James. The Politics of the Third World. London: Oxford University Press, 1986.

Modelski, George. A Theory of Foreign Policy. London: Pall Mall Press, 1962.

Northedge, F.S. and M. Dondan. International Disputes: The Political Aspects. London: Europe Publications, 1981.

Northedge, F.S. The Foreign Policies of the Power. London: Faber and Faber Ltd; 1984. 
Brecher, Michael. "Krishna Menon's View of the World", in James Barber and Michael Smith (eds.). The Nature of Foreign Policy: A Reader. Edinburgh: Holmes McDougall, 1984.

Brecher, Michael. "Research Findings and Theory Building in Foreign Policy Behavior", in Patrick McGowan (ed) International Year Book of Foreign Policy Studies, Vol. 2. London: Sage Publications, 1984.

Coplin, William and Charles Kegley. A Multi-Method Introduction to International Relations. Chicago: Markham Publishing Co., 1981.

Coplin, William. Introduction to International Politics. Chicago: Rand McNally College Publishing Co., 1984.

Dawisha, Adeed. "The Middle East", in Christopher Clapham and William Wallace (eds.). Foreign Policy-Making in Developing States: A Comparative Approach. Westmead: Saxon House, 1977.

Dougherty, James and Robert Pfaltzgraff. Contending Theories of International Relations. N.Y.: J.P. Lippincott Co., 1981.

East, Maurice and Phillip Gregg. "Factors Influencing Cooperation and Conflict in the International System". International Studies Quarterly, Vol. 11, (September 1967).

Frankel, Joseph. British Foreign Policy 1945-1973. London: Oxford University Press, 1975.

Frankel, Joseph. National Interest. London: MacMillan Press, 1970. 
One method of examining foreign policy decisions is to divide them into categories. Such separation is of considerable value in promoting accurate analysis. William Coplin divides foreign policy decisions into three categories:

1. General foreign policy decisions.

2. Administrative decisions.

3. Crisis decisions. ${ }^{[41]}$

One question remains to be answered. That is, who is the decision-maker? Answering such a question leads us by necessity to the state's political system. The decision-maker could be a dictator, a constitutional monarch, an elected prime minister, a secretary-general of a party, a ruler or a president. The status of the decision-maker determines to a-major extent his power. He might simply be able to make a decision without referring to any of his assistants, or he could form and ad hoc group to advise him on what action to take. A decision-maker's role in a democratic state with a strong parliament, free press, strong opposition and interest and pressure groups differs fundamentally, for example, from that of a monarch in a third world country, where no legal outlets exist for the expression of opposition, and from the leader of a junta who may consult only his fellowofficers.

\section{References}

Barber, James and Michael Smith. The Nature of Foreign Policy: A Reader. Edinburgh: Holmes McDougall, 1984.

${ }^{[41]}$ Coplin, op.cit., PP.31-34. 
reality, not in response to reality itself. ${ }^{[37]}$ The images they form are crucial, for the decisions they make depend on the perceived psychological environment and not on the real world in which their decisions have to be implemented. The dilemma here is that discrepancies between the psychological and the operational environments can have grave consequences. ${ }^{[38]}$

Decision-makers make assumptions and have their own personal perceptions. Both assumptions and perceptions affect a decision-makers activity. In theory, the two terms "assumption" and "image" or "perception" are fundamentally different. "Assumption" refers to taking things for granted, whereas "image" refers to the perception and evaluation of reality; assumptions are generally unspoken and refer to the beliefs which are fundamental and upon which one's reasoning rests; whereas images have much closer links with one's consciousness and with real life. In fact both are based upon political culture and lifetime experiences. ${ }^{[39]}$

In addition, no matter how hard decision-makers try to see the world as it really is, they can never do so, for the complexity of the world makes them see the world only in terms of partial selection from its multifarious reality. ${ }^{[40]}$

\footnotetext{
[37] Michael Brecher, "Krishna Menon's View of the World," in James Barber and Michael Smith (eds.), The Nature of Foreign Policy: A Reader, (Edinburgh: Holmes McDougall, 1984), P.264.

[38] Joseph Frankel, National Interest, (London: MacMillan Press, 1970), P.40.

Joseph Frankel, British Foreign Policy 1945-1973, (London: Oxford University Press, 1975),
P.89.

${ }^{[40]}$ F.S. Northedge and M. Dondan, International Disputes: The Political Aspects, (London: Europe Publications, 1981), P.28. 
Or as Richard Rosecrance puts it: "external influences derive from the fact that a nation-state exists in a field of others, at least, partially competing nation-states. It can never ignore the field of competitors, for if it does so, it risks its own survival". [34]

\section{(C) The Decision-Making Process:}

In foreign policy decision-making, decision-makers act on the basis of their experience and historical background, their images of other actors, their perceptions and expectations, their personal values and the information available to them before taking

a decision. The classical conception of decision-making assumed the decisionmaker to be a rational man who knew all possible alternatives, understood the possible consequences of each of these alternatives and arrived at a clear hierarchy of preferences among them. ${ }^{[35]}$ Contemporary theorists, however, define decision-making as the act of choosing among available alternatives - about which a certain amount of uncertainty exists. ${ }^{[36]}$

What makes the process difficult is the fact that foreign policy decision-makers are human beings confronted with specific situations, responsible to other human beings, pressured by a variety of conditions, and forced to make decisions. When they take a decision, moreover, they do so in accordance with their perception of

[34] Richard Rosecrance, International Relations: Peace or War, (N.Y.: McGraw Hill Book, 1983), P.167.

[35] James Robinson and Richard Snyder, "Decision-Making in International Politics", in Herbert Kelman (ed.), International Behavior: A Social-Psychological Analysis, (N.Y.: Holt, Rinehart and Winston, 1985), PP.437-438.

[36] James Dougherty and Robert Pfaltzgraff, Contending Theories of International Relations, (N.Y.: J.P. Lippincott Co., 1981), P.312. 
one economy to another have often been the scene of war". ${ }^{29]} \mathrm{L}$. Richardson supports this argument and asserts that states have tended to become involved in wars in proportion to the number of states with which they have common frontiers. ${ }^{[30]}$ Other studies suggest that there is a relationship between a nation's regional position and its voting in the United Nations, ${ }^{[3]}$ and that the less the geographic distance between nations, the greater the interactions between them. ${ }^{[32]}$

The argument of those theorists who lay emphasis on the geographic element's crucial role in the conduct of foreign policy is countered by others who minimize this role. The argument of the latter theorists is that this is the era of science and technology where distances, size, and locations have only a peripheral significance. In our view the geographic element is still crucial regardless of the changes brought about by science and technology. It is sufficient to follow the rivalry that is taking place even today between the great powers and their allies to gain footholds in different parts of the world to make us realize the great importance of the geographic element.

To summarize, the external environment provides us with a very important category through which the influence of foreign policy formulation can be analyzed. In the words of Maurice East and Phillip Gregg, "nations' actions in the international system are systematically rather than randomly associated with their international situation". [33]

[29] Wright, op.cit., P.122.

[30] McGowan and Shapiro, op.cit., P.163.

[31] Ibid, P.167.

[32] Ibid, P.171.

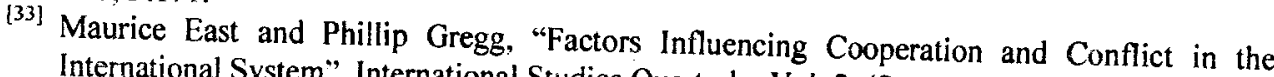
International System", International Studies Quarterly, Vol. 2, (September 1967), P.265. 
principal factor conditioning its foreign policy, but "the principal reason why it must have a foreign policy at all". [25]

To illustrate the importance of geographic location, Roy Jones argues that: "a small land-locked state must keep a closc cyc on the continental balance of power. A maritime state must be anxious to maintain freedom of sea communications. A state whose access to the sea is impended by ice over much of the year will be interested in acquiring ports free from this impediment. A continental first rank state will be watchful of efforts to subvert surrounding states". ${ }^{[26]}$ Roy Jones concludes by saying that: "in ways like these the longstanding existence of the state in given geographical circumstances seems to establish specific concerns that together comprise an interest that no statesman can neglect". [27]

Many studies have been carried out to examine the influence which the geographical element exerts on foreign policy-making (by means of affecting the nature of the international environment). One study suggests that geographic contiguity tends to increase a nation's involvement in foreign conflict. Nations contiguous to many other nations are likely to participate in more violent foreign conflict than geographically isolated states. ${ }^{[28]}$ Quincy Wright modifies that finding when he links it with the type of economy contiguous states have. Wright states that "geographic frontiers marking the transition from

\footnotetext{
[25] Harold and Margaret Sprout, "Environment Factors in the Study of International Politics", in James Rosenau (ed.), International Politics and Foreign Policy: A Reader in Research and Theory, (N.Y.: The Free Press, 1969), P.41.

[26] Roy Jones, Principles of Foreign Policy, (Oxford: Martin Robertson Co., 1979), P.36.

[27] Ibid.

[28] Patrick McGowan and Howard Shapiro, The Comparative Study of Foreign Policy, (London: Sage Publications, 1983), P.163. 
which the state belongs such pressures are classified as foreign policy inputs from other subordinate systems.

4. Dominant bilateral relations: The total pattern of interactions between any state and superpower.

5. Bilateral relations: The total pattern of interactions between two states except for those involving one of the superpowers. $^{[23]}$

In an effort to classify influences coming from the international environment, Harold and Margaret Sprout see a number of international political systems as being in existence, ranging from a global system to regional and other less-than-global systems. The global international system includes all members of the society of nations. It is linked with international organizations like the United Nations. Regional and less-than-global systems are subsystems of the global international political system. The organization of American states, the British Commonwealth, NATO, the EEC, etc... all fit into this category. All regional and other less-than-global international systems are linked in various ways to the global system. ${ }^{[24]}$

The element which has the greatest effect in determining the nature of the international environment encompassing a state is geographical location. This is the most central and permanent of all determinants. The geographical position of a nation is not only the

\footnotetext{
[23] Michael Brecher, "Research Findings and Theory Building in Foreign Policy Behavior", in
Patrick McGowan (ed.), International Year Book of Foreign Policy Studies, Vol. 2, (London:
Sage Publications, 1984), PP. 60-61.

[24] Harold and Margaret 1984), PP. 60-61.

Co., 1972), PP.88-89.
} 
services in the external world of any polity are created, processed and utilized. The last of these categories is the organizational environment which encompasses all those organizations that have structure and personnel apart from the polities belonging to them, such as the United Nations and the International Court of Justice. ${ }^{|22|}$

Michael Brecher suggests another scheme for the sub-division of the international environment. Brecher believes that inputs coming from the external environment can logically be divided into five components:

1. The global system: This comprises the total web of relationships among all actors within an international system. Brecher argues that in the late twentieth century three types of interaction at the global level provided the most important boundaries for state behavior: relations between the capitalist and socialist camps; the behavior of the United Nations; and relations between the superpowers and the third world.

2. A subordinate system: There are, according to Brecher, at least six subordinate systems of the regional type in the present international system: West European, East European, American, Middle Eastern, Southern Asian and Sub-Saharan African.

3. Other subordinate systems: States may be members of one subordinate system, more than one, or none at all. When pressures emanate from a system other than one to 
conditions existing abroad that might stimulate official action. Rosenau mentions diplomatic incidents, deteriorating economies, crop failures, military buildups, elections and historic enmities. ${ }^{[2]}$ James Rosenau, on the other hand, suggests that the international environment in which contemporary states move can be conceived in terms of six different kinds of environments:

1. The contiguous environment.

2. The regional environment.

3. The great power environment.

4. The racial environment.

5. The resource environment.

6. The organizational environment.

The contiguous environment category refers to any cluster of polities that border geographically upon a given polity. In the case of the regional environment, the scope is extended to include the entire region in which a given polity is located. The size of a region can range from a small area, (such as Central America), to regional entity, (e.g. the Arab world), and even to entire continents (e.g. Europe). The great powers environment forms a category because polities can hardly remain unaffected by the ways in which East and West relate on many matters irrespective of being sometimes geographically removed from the two power-blocs. The racial environment deals with expectations, trends and conflicts external to a polity that pertains to relations between racial or ethnic groups. The resource environment encompasses all activities through which goods and
[21] Rosenau, op.cit., PP.80-81.
$-8-$ 
makers, the way in which they become important is closely linked to the decision-making formula. ${ }^{[16]}$

Although foreign policy-making is deeply affected by both domestic and international environments, it does nevertheless constitute a distinct field-forming. in fact, a bridge between the two environments. ${ }^{[17]}$ In the words of Norman Padelford and George Lincoln, "a state's foreign policy is essentially an extension of its domestic purposes to its dealings with the world beyond its borders". ${ }^{[18]}$ Studying foreign policy involves an understanding of both the domestic and external environments and then the relating of one to the other. ${ }^{[19]}$

Let us look closely now to the external environment, the scope of its influences and the different variables involved.

\section{(B) The External Environment:}

Adeed Dawisha believes that external environment is "all situational and relational conditions and activities existing outside the territorial boundary of the state". ${ }^{[20]}$ To illustrate the manner in which the external environment impinges on foreign policy-making; James Rosenau gives some examples of developments taking place and

\footnotetext{
[16] Fred Sondermann, William Olson and David McLellan, The Theory and Practice of International Relations, (Englewood Cliffs: Prentice-Hall, 1983), P.100.

[17] James Barber and Michael Smith, The Nature of Foreign Policy: A Reader, (Edinburgh: Holmes McDougall, 1984), P.11.

${ }^{[18]}$ Norman Padelford and George Lincoln, The Dynamics of International Politics, (London: MacMillan Press, 1972), P.228.

[19] Jon Glassman, "Soviet Foreign Policy Decision-Making", in Andrew Cordier (ed.), Columbia Essays in International Affairs, Vol. 3, (N.Y.: Columbia University Press, 1978).

[20] Adeed Dawisha, "The Middle East", in Christopher Clapham and William Wallace (eds.), Foreign Policy-Making in Developing States: A Comparative Approach, (Westmead: Saxon House, 1977), P.44. 
context. ${ }^{[12]}$ James Miller supports Rosenau's finding and adds that countries with compatible domestic conditions and historical experiences would seek common goals in their external conduct. Miller notes that most third world countries adopt similar foreign policies, bearing a generally anti-colonialist character. ${ }^{[13]}$

No matter how important the role played by the domestic environment on the making of foreign policy is, insights and generalizations are not easily found because that role varies given the type of state involved. In a democratic state, the decision-maker always needs to bear in mind views expressed by the press and public opinion, while in a country ruled by a military junta such elements play only a small role. ${ }^{[14]}$

The domestic environment is also important because the internal political situation determines how forcefully a government can play its diplomatic hand; what it cannot do for fear of losing support at home, what it must do, or try to do if it is to hold its own against the opposition. ${ }^{[15]}$ Some authorities have suggested that as domestic environmental factors become important and relevant only to the extent that they are perceived and taken into account by policy-

[12] Rosenau, op.cit., P.399.

[13] James Miller, The Politics of the Third World, (London: Oxford University Press, 1986), P.13.

[14] William Coplin and Charles Kegley, A Multi-Method Introduction to International Relations, (Chicago: Markham Publishing Co., 1981), PP.77-78.

${ }^{[15]}$ F.S. Northedge, The Foreign Policies of the Power, (London: Faber and Faber Ltd., 1984), PP.22-23. 
governmental agencies (i.e. political parties, interest groups, communications media); characteristics of public opinion ${ }^{[6]}$; the diplomatic service ${ }^{[7]}$; and science and technology. ${ }^{[8]}$

Although some scholars see domestic politics as only one key to understanding any state's foreign policy. ${ }^{[9]}$ others ascribe to domestic politics the most fundamental influence believing that the foreign policy of a government is the reflection of its internal policy. ${ }^{[10]}$ To show the great importance which can be attached to the domestic environment, Henry Kissinger explains hostility to western countries usually displayed by leaders of developing countries as means of overcoming or diverting attention from ethnic, religious and ideological divisions. Kissinger believes that the international arena provides as an opportunity for taking dramatic foreign policy measures that are impossible at home. Quincy Wright puts it this way, "a ruler prevents sedition by making external war". ${ }^{[1]}$ In other words, in order to create national unity, governments may undertake foreign adventures.

Although James Rosenau does not attribute everything to the - domestic environment, he does accept that foreign policy does partially reflect it. The goals, contents and style of foreign policy are, Rosenau contends, to a significant extent, shaped by the domestic

\footnotetext{
[6] Roy Macridis, Foreign Policy in World Politics, (Englewood Cliffs: Prentice-Hall, 1977), P.5.

[7] George Modelski, A Theory of Foreign Policy, (London: Pall Mall Press, 1962), PP.72-73.

[8] Rouhollah Ramazani, The Foreign Policy of Iran 1500-1941, (Virginia: University of Virginia Press, 1966), P.9.

[9] William Coplin, Introduction to International Politics, (Chicago: Rand McNally College Publishing Co., 1984), P.66.

[10] Robert Jervis, Perception and Misperception in International Politics, (Princeton: Princeton University Press, 1976), P.23.

[11] Quincy Wright, A Study of War, (Chicago: University of Chicago Press, 1965), P.140.
} 
The domestic environment includes numerous factors affecting the external behavior of the state. For James Rosenau these factors are:

1. The military strength of the state.

2. Economic and social conditions.

3. The role of the press.

4. The personality of the decision-maker and his background. ${ }^{[2]}$

Henry Kissinger suggests the following factors:

1. Historical traditions.

2. Social values.

3. Economic system.

4. The administrative structure.

5. The formative experience of leadership groups. ${ }^{[3]}$

Some scholars make use of such categories as the level of education and health; the type of government the state contains; the extent of internal disturbances such as riots, revolutions ${ }^{[4]}$; topographical features; demographic characteristics ${ }^{[5]}$; natural resources (i.e. minerals, agricultural resources, energy and power); industrial establishment; roles of ideology and information; non-

[2] James Rosenau, The Scientific Study of Foreign Policy, (N.Y.: Nichols Publishing Co., 1980), P.96-97.

[3] Henry Kissinger, "Domestic Structure and Foreign Policy", in James Rosenau (ed.), International Politics and Foreign Policy: A Reader in Research and Theory, (N.Y.: The Free Press, 1969), P.263.

[4] Dina Zinnes, "Some Evidence Relevant to the Man-Milieu Hypothesis", in James Rosenau (ed.), The Analysis of International Politics, (N.Y.: The Free Press, 1982), P.214.

[5] K.J. Holsti, "Domestic Factors and Foreign Policy Output", in James Barber and Michael Smith (eds.), The Nature of Foreign Policy: A Reader, (Edinburgh: Holmes McDougall, 1984), P.106. 
We have no intention of adding to the confusion of theories, models, and analytical frameworks already existing in the field of foreign policy. The objectives of this study are rather: 1) to summarize the main trends and approaches in the study of foreign policy, 2) to survey the literature on foreign policy, and 3) to suggest a framework for analysis that takes into account the major conceptual contributions in foreign policy theory in the last two decades.

\section{The Determinants of Foreign Policy:}

We will start by examining the different ways in which theorists have classified the determinants of foreign policy. As all theories of foreign policy divide the factors influencing policy into "domestic" and "external" categories, this basic division will be adhered to here.

\section{(A) The Domestic Environment:}

The term "environment" is widely used in the literature of international relations despite some reservations which have been expressed on the usage of the term. Harold and Margaret Sprout, for example, use the French term "milieu" instead the term of "environment" because they believe there is a tendency to restrict "environment" to non-human factors. For them "milieu" by definition includes both human and non-human, intangible, as well as tangible factors. ${ }^{[1]}$ However, it seems that the Sprout's term has not been commonly used in international politics literature, so "environment" will be retained in this study.

[1] Harold and Margaret Sprout, The Ecological Perspective on Human Affairs with Special Reference to International Politics, (Princeton: Princeton University Press, 1975), P.27. 


\section{The Determinants of Foreign Policy}

\section{ABDUL RAHMAN AL-ANGARI \\ Associate Professor \\ Political Sciences Department \\ King Saud University}

\section{Introduction:}

Foreign policy can be thought of as the process through which states translate their goals and objectives related to the external environment into courses of action. While the factors affecting foreign policy vary from state to state, it is possible to create for all states a framework within which the different factors may be differentiated and categorized. The most fundamental aspect of such a framework must be the distinction between the external environment, the domestic environment and the decision-making unit.

Foreign policy-making cannot be divorced from either the society out of which it emanates or from the circumstances abroad towards which it is directed, with the result that some external and internal variables will be present in every undertaking.

Although the study of foreign policy has advanced considerably in recent years, both in the development of concepts and in the use of empirical data, there is not single theoretical scheme of analysis, nor any standard methodology. In short, there are a number of theoretical approaches that various scholars have either identified or developed. 


\section{The Determinants of Foreign Policy}

\section{ABDUL RAHMAN AL-ANGARI}

Associate Professor

Political Sciences Department

College of Administrative Sciences

King Saud Vniversity

Riyadh, Saudi Arabia 